ECONOMICS

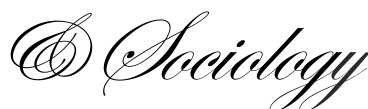

\author{
Diep Thanh Tung, \\ Tra Vinh University, \\ TraVinh, Vietnam, \\ E-mail:dttung@tvu.edu.vn
}

Received: August, 2017

1st Revision: November, 2017

Accepted: January, 2018

DOI: $10.14254 / 2071-$

789X.2018/11-1/15
Tung, D. T. (2018). Poverty and Ethnic Minorities: The Case of Khmer

Households in the Rural Mekong Delta, Vietnam. Economics and Sociology, 11(1), 233-244. doi:10.14254/2071-789X.2018/11-1/15

\title{
POVERTY AND ETHNIC MINORITIES: THE CASE OF KHMER HOUSEHOLDS IN THE RURAL MEKONG DELTA, VIETNAM
}

\begin{abstract}
Poverty reduction is one of the outstanding achievements associated with Vietnam's economic growth. However, reducing poverty and inequality among various ethnic groups in Vietnam may be different. The Khmers are one of the ethnic minorities in the country, with their distinctive cultural structure and large populations throughout the country. They live mainly in the Mekong Delta. This study surveyed $390 \mathrm{Khmer}$ households in rural areas of the Mekong Delta to assess their poverty situation and their capacity for income diversification as the way to minimize income fluctuations and vulnerability. The findings reveal that the average income of a Khmer household was much lower than households' average income in the whole region, evenly compared to the same indicators the same region four years ago. Limited areas of agricultural land per household and low education level among the local laborers are the important factor contributing to the dependence of households on low-skill jobs, thus resulting in low wages. In terms of poverty reduction among policies Khmer households, income diversification, access to education, infrastructure and credit have shown some positive effects on the probability of a household to escape poverty. Gender inequality and regional disparities are other significant factors in this regard, and thus they need to be addressed in the future policies design.
\end{abstract}

JEL Classification: I30,D33 Keywords: poverty; inequality; income diversification; Khmer.

\section{Introduction}

Vietnam's economic growth and poverty reduction have made impressive gains over the past two decades. Vietnam was one of the countries achieving the Millennium Development Goals in 2015, including: (i) eradication of extreme poverty and hunger, (ii) achieving universal primary education, (iii) promoting gender equality and empowering women. Particularly on poverty reduction, according to the aggregate data of MPI (2015), the poverty rate declined from $58.1 \%$ in 1993 to $19.5 \%$ in 2004, thus getting 20 million people out of poverty. Similarly, in the period from 2011 to 2015 , the poverty rate again dropped significantly, now from $14.2 \%$ in 2010 to $9.8 \%$ in 2013 . 
However, these achievements in poverty reduction have been associated with many internal challenges. Kozel (2014) has pointed out that the speed of poverty reduction in Vietnam has slowed down while the poverty rate in mountainous and remote areas remained to be high. The multidimensional poverty has been more pronounced through urbanization and migration. In particular, income inequality is increasing, as shown by the increasing Gini coefficient in the country - from 0.418 in 2000 to 0.43 in 2010. Moreover, "Growth in rural areas has been far higher among richer households than among poorer households; growth in the poorest 10 percent of households was less than half that seen in the richest 10 percent of households" (Kozel, 2014, p. 201). In addition to that, socioeconomic development rates among various ethnic groups are very different. The Report of the Committee for Ethnic Minority Affairs (2015) showed that the poverty rate of ethnic minorities in Vietnam was still very high $(48.7 \%$ back in 2013) and approximately $10 \%$ of ethnic minority households were still suffering from hunger. The poverty gap between Kinh majority and ethnic minorities has also increased sharply. According to Nguyen Thi Thu Ha et al. (2015), the probability of a minority living under poverty line was normally 5.1 times higher than that of the Kinh majority by 2010, while back in 1993 this gap was only 1.6 times.

In addition, there were significant differences in the achievements related to poverty reduction across the regions. According to the data as of 2012 by GSO (2014), the poverty rate in the Northwest of the country was $58.7 \%$, the highest level compared to other regions in the country. The poverty rate as of 2012 in the Mekong Delta was $16.2 \%$. Although the poverty rate of the Mekong Delta is the fourth lowest among the eight regions of the country, the region still faces its own challenges related to poverty. Differences in economic conditions among ethnic groups are highly important in this regard.

In the country overall, the Khmers mainly live in the Mekong Delta, where they are the largest ethnic minority group as compared to others in this region. According to GSO (2010), there were over 17 million people in the Mekong Delta and 53 ethnic groups (excluding foreigners living in Vietnam). The Khmer population was the second largest group of over 1.1 million people, of which approximately 1 million are living in rural areas (GSO, 2010). Three provinces with the highest concentration of the Khmer population were Soctrang (397,014 people), Travinh (317,203) and Kiengiang (210,899) (GSO, 2010).

Very few publications have addressed the situation and sustainable economic development of the Khmer minority in Vietnam. Among these studies, the Khmer households' economic situation was mostly described as lagging behind as compared to the Kinh's economic development. At this, it is often emphasized that the Khmers' livelihoods mainly rely on agriculture and thus they are facing many related risks (GSO, 2014; Anh and Nghia, 2014; Duyen, 2015). For this reason, income diversification might play a vital role. Theoretically, a number of studies on income diversification and poverty have found that diversification of income was the means for generating sustainable livelihoods for such as households (Dimova and Sen, 2010), the strategy for increasing incomes and reducing poverty (Ellis, 2000; Ibrahim et al., 2009; Zhao and Barry, 2014), and minimizing risks and fluctuation in incomes (Adebeyo et al., 2012; Abdulai and CroleRees, 2001). In addition, income diversification plays an important role in contributing to raising households' welfare level (Khai et al., 2013; Sultana et al., 2015).

In contrast, poverty could cause reduced access to strategic diversification (Barrett et $a l ., 2001)$. However, in some other specific studies, the relationship between poverty and impact from diversification is not always that obvious (Christiaensen et al., 2013). In the case of Vietnam, the study by Van De Walle and Cratty (2004) illustrated that the factors affecting poverty and income diversification were not the same. Meanwhile, economic problems might be the cause of other social problems. A recent study by Oxfam (2013) reported that a relationship exists between increasing inequality and social structure shifts, which impacted the 
trust of people in institutions and society. Increasing inequality could have further political and social implications for the whole region.

The major objective of this study is to examine the evidence of the Khmers' sustainable economic development status in Vietnam and to assess the determinants of poverty and income diversification among the Khmer population. The remainder of this paper is organized in three sections, including analytical methods and materials, results, and conclusion.

\section{Methodological approach}

\subsection{Measuring poverty and its determinants}

In Vietnam, there are two systems for the identification of poor households, and they are implemented in parallel, including the MOLISA poverty monitoring system and another GSO-WB integrated monitoring system. Although each system can have different measurement objectives (Demombynes and Hoang Vu, 2015), the system of MOLISA is still applied officially in the country. A household that meets the MOLISA evaluation criteria will be issued a poverty certificate. In this study, a household was identified as a poor household if the household had a poverty certificate.

Accordingly, this study uses the binary logistic regression model. The dependent variable is a dummy variable with a value of 1 if the household hold poverty certification and 0 if none. Call $p_{i}$ is the probability of household $\mathrm{i}^{\text {th }}$ to be a poor household with poverty certificate. Then $\left(1-p_{i}\right)$ is the probability of non-poor household. The relationship between the independent variables and the dependent variable can be expressed in terms of the equation:

$$
\log \left(\frac{p_{i}}{1-p_{i}}\right)=\propto+\beta_{j} X_{j}+\varepsilon
$$

where $\mathrm{X}_{\mathrm{js}}$ are independent variables; $\beta_{j}$ is the coefficient of $\mathrm{X}_{\mathrm{j}}$, and $\varepsilon$ is residue.

\subsection{Measuring income diversification and its determinants}

To measure the variation in the household's income, a number of indicators are used frequently in existing studies, including (i) the GINI index: This common index is used to measure inequality in a single indicator. Some studies applied this index for income inequality measurement and the diversification of the various income sources (Escobal, 2001; Malek and Usami, 2009); (ii) the Simpson index: the most typical method is found in measuring diversification of income sources (Bernard et al., 2014; Ibrahim et al., 2009; Minot et al., 2006; Sultana et al., 2015) or similarly (iii) the Herfindahl index (Adebeyo et al., 2012). In addition, some studies used a number of other indicators to measure the diversification of income sources such as the Shannon equitability index (Schwarze and Zeller, 2005) the Shannon-Weaver index (Minot et al., 2006).

In this study, the Simpson index was employed because it is one of the most practical indices to measure income diversification. Basically, the Simpson index (Simpson's Diversity Index - SDI) uses algorithms to measure diversification by the sum of squares of income types:

$$
D=\sum_{i=1}^{n} p_{i}^{2}
$$

where $\mathrm{p}$ is the proportion of different types of income of the household. However, the SDI is usually expressed in the form 1-D, to ensure that the SDI will have a value between 0 and 1 . 


$$
S D I=1-\sum_{i=1}^{n} p_{i}^{2}
$$

Then, if the SDI value is zero, household income is dependent on a single source of income, if the SDI value is 1 , the household's income is at the highest level.

To analyze factors affecting income diversification, the SDI is used as a dependent variable to estimate the impact of exogenous variables by a regression analysis. The common regression technique consistent with this objective could include: OLS (Ibrahim et al., 2009; Zhao and Barry, 2013); Multinomial logit (Wanyama et al., 2010), Quantile regression (Zhao and Barry, 2013); Conditional logit fixed effects model (Abdulai and CroleRees, 2001); Tobit regression (Adebeyo et al., 2012; Bernard et al., 2014; Malek and Usami, 2009; Schwarze and Zeller, 2005; Wanyama et al., 2010).

Similar to the definition of income diversification indicators, the choice of the model represents the factors that influence the income diversification depending on the effectiveness of each type of model for the analytical goal and the type of data and variables included in the analysis model. This study proposes to use the Tobit censored regression model to measure the impact of these factors on the index to diversify income SDI (the upper level and lower level of 1 and 0 with respect to the maximum and minimum values of SDI). The model is described in detail as follows:

$$
\begin{aligned}
& S^{*}=\beta_{0}+\beta_{1} X_{1}+\beta_{2} X_{2}+\cdots+\beta_{n} X_{n}+u \\
& S=\left\{\begin{array}{l}
0 \text { if } S^{*} \leq 0 \\
1 \text { if } S^{*} \geq 1 \\
S^{*} \text { if } 0<S^{*}<1
\end{array}\right.
\end{aligned}
$$

where $S^{*}$ is a latent variable corresponding to the expected value SDI and $S$ is the real value of the $\mathrm{SDI} ; \mathrm{X}_{1}, \mathrm{X}_{2}, \ldots, \mathrm{X}_{\mathrm{n}}$ are respective independent variables; $u$ is a normally distributed error term.

In both of these models, the relationship between poverty and income diversification has been demonstrated in a number of studies. In Vietnam, the study of Khai et al. (2013) argued that income diversification is the factor that increases the social welfare of households; although there are differences between regions in Vietnam. The two changes in poverty and income diversification will be as variable interactions in the model. Some of the remaining independent variables in both models are expected to include: age (Bernard et al., 2014; Ibrahim et al., 2009), the level of the household head (Adebeyo et al., 2012; Alobo, 2012; Ibrahim et al., 2009), female-headed households (Bernard et al., 2014), farm size (Adebeyo et al., 2012; Alobo, 2012; Wanyama et al., 2010), the number of household workers(Ibrahim et al., 2009; Minot et al., 2006), the participation of the members of the households in the social, economic organizations (Adebeyo et al., 2012), the role of agricultural extension (Bernard et al., 2014; Ibrahim et al., 2009), income from non-agricultural activities (Adebeyo et al., 2012), the degree of infrastructure development (Bernard et al., 2014; Ibrahim et al., 2009), market access (Alobo, 2012) and access to credit (Alobo, 2012; Schwarze and Zeller, 2005; Wanyama et al., 2010) and migration opportunities (Alobo, 2012).

\subsection{Data and study area:}

As mentioned, there are approximately 1.1 million Khmers in Vietnam with roughly 1 million Khmer people living in rural areas. According to the principles for determining the sample size of Morris Hamburg and Andrea Lubov (1985), the minimum sample size of the study will be approximately 384 households with respected parameters including the total 
population of approximately 300,000 Khmer households (1.1 million Khmer people and 4 persons per household based on preliminary survey results in combination with 95\% confidence level and 5\% error margin). For prevention of insufficient observations, the initial sample consisted of 420 households in rural areas of the Mekong Delta, including Soctrang province (179 households), Travinh province (145 households) and Kiengiang province (96 households). The sample of each province was calculated based on their proportions to the total Khmer population in the country. The questionnaire was designed similarly to the questionnaire of the Household Living Standard Survey 2010 (GSO, 2010) in order to incorporate all aspects of household's livelihood. All questionnaires were thoroughly checked for removing questionnaires with incomplete data. The final sample of households remained at 390 households, meeting the minimum sample size.

The data collected through this study is expected to be comparable to the existing data, such as the Vietnam Household Living Standards Survey reflect difference by ethnic groups and by time. The questionnaire; therefore, is designed similarly to the one of the Vietnam Household Living Standards Survey. The sources of household income were categorized into five sources, including incomes from cultivation, livestock, and aquaculture, paid employment, off-farm activities, and subsidies.

\section{Conducting research and results}

\subsection{Income and income diversification of Khmer households in rural areas}

The most remarkable finding of this study reflected that the average annual income of a Khmer household in rural areas is only 72.560 million VND per household in 2016. With the average household size of 4.08 household members, the average income per person was only 1.482 million VND per month (approximately $\$ 60$ per month). The average income per person of poor households was 1.182 million VND while the respective income of the non-poor household was 1.626 million VND. As mentioned, it is noteworthy that this total income included all subsidies from their relations or from the governments for the poor households. It means that income after subsidies and the real income earned by the households is even lower. Although there was a significant difference between the income of poor and non-poor households, it was not much. On the other hand, there exists a big gap in the household income between the Khmer minority and the Kinh majority. The monthly average income per person of the Khmer was compared to the data from the 2012 Vietnam Household Living Standards Survey (GSO, 2012). It indicated that the monthly average income per person in rural areas of the country in 2012 (1,579 million), and the respective income per person in both rural and urban areas of the Mekong Delta in 2012 (1,796 million). The findings raised the question whether the Khmer minority was lagging behind compared to the average of the region for more than four years in terms of average income.

To analyze the difference in specific income sources between poor and non-poor households, the T-test was employed. It returned meaningful results with two characteristics noted: (i) Most of the income sources of non-poor households were higher than the respective income sources of poor households, except the income from paid employment; (ii) there was a significant difference between the two household groups in total income and the income from agricultural activities. The average income from agricultural activities of non-poor households was approximately eight times higher than poor households. The findings of (i) and (ii) implied that access to agricultural land might play an important role in the households' income structure. As a consequence, the main income source of the landless households significantly depends on the paid employment. 
Specifically, the findings indicated that the average area per household was only $5,126 \mathrm{~m}^{2}$, whereas the agricultural land area was $4,290 \mathrm{~m}^{2}$ on average. Among the 390 households surveyed, $5.64 \%$ of households had no land and approximately $50 \%$ of households had no agricultural land. Owning no or only very small agricultural land areas was the main reason of the low agricultural income in the households' income structure. According to the surveyed data, the income structure of Khmer households in rural Mekong Delta was based on five main sources: the ratios of each income source were (i) crop (18.78\%), (ii) livestock and aquaculture (10.45\%), (iii) paid employment $(68.11 \%)$, (iv) unpaid non-farm work as self-business $(2.05 \%)$, and (v) subsidies and other incomes $(0.61 \%)$. In particular, paid employment (employed in the agricultural and non-agricultural sectors) accounted for the highest proportion of total income. Again, we compared these findings to the results of the 2012 Vietnam Household Living Standards Survey. The share of paid employment of households in rural Vietnam was approximately $38.4 \%$. Furthermore, $30.6 \%$ of households' income was from agriculture and fisheries (GSO, 2012). In other words, this finding indicated that the Khmer households much depended on paid employment compared to the typical income structure of the rural household in Vietnam. Approximately $65 \%$ of Khmer household heads with the education level at elementary or lower were found in this study sample, this rate was a visible challenge for the Khmer labor to gain higher earnings from paid employment.

Table 1. Difference between poor and non-poor households on some main indicators

\begin{tabular}{|c|c|c|c|c|c|c|c|}
\hline \multirow[t]{2}{*}{ Variable explanation } & \multicolumn{4}{|c|}{ Overall } & \multicolumn{2}{|c|}{$\begin{array}{c}\text { Poor Non-poor } \\
\text { households households }\end{array}$} & \multirow{2}{*}{$\begin{array}{c}\mathrm{T}- \\
\text { value } \\
\text { test }\end{array}$} \\
\hline & Mean & Std. Dev. & Min & Max & Mean & Mean & \\
\hline \multicolumn{8}{|l|}{ Income } \\
\hline Total income (1,000 VND/year) & $72,560.530$ & $97,441.060$ & 1,600 & 122,150 & $57,964.460$ & $79,608.830$ & $* *$ \\
\hline Cultivation & $13,626.500$ & $79,042.040$ & 0 & 122,150 & $2,119.094$ & $19,183.300$ & $* *$ \\
\hline Livestock and aquaculture & $7,581.655$ & $19,739.510$ & 0 & 14,000 & $2,581.654$ & $9,996.105$ & $* * *$ \\
\hline Paid employment & $49,420.490$ & $58,587.790$ & 0 & 88,000 & $52,273.400$ & $48,042.850$ & \\
\hline Off-farm activities & $1,490.789$ & $10,749.880$ & 0 & 18,000 & 686.063 & $1,879.383$ & \\
\hline Subsidies & 441.100 & $2,787.1380$ & 0 & 4,000 & 304.244 & 507.186 & \\
\hline \multicolumn{8}{|l|}{ Land } \\
\hline Total land area $\left(\mathrm{m}^{2}\right)$ & $5,126.354$ & $8,981.498$ & 0 & 73,100 & $1,868.118$ & $6,699.722$ & $* * *$ \\
\hline Agricultural land & $4,290.015$ & $7,439.418$ & 0 & 40,000 & $1,623.228$ & $5,577.779$ & $* * *$ \\
\hline Annual crop land & $4,074.015$ & $7,243.635$ & 0 & 40,000 & $1,497.244$ & $5,318.312$ & $* * *$ \\
\hline Perennial tree land & 216.000 & $1,566.557$ & 0 & 22,000 & 125.984 & 259.468 & \\
\hline \multicolumn{8}{|l|}{ Income diversification index } \\
\hline Overall SDI & 0.132 & 0.182 & 0 & 0.650 & 0.076 & 0.159 & $* * *$ \\
\hline SDI of Kiengiang & 0.102 & 0.169 & 0 & 0.512 & 0.034 & 0.123 & $* *$ \\
\hline SDI of Soctrang & 0.125 & 0.173 & 0 & 0.648 & 0.075 & 0.150 & $* * *$ \\
\hline SDI of Travinh & 0.159 & 0.198 & 0 & 0.650 & 0.094 & 0.198 & $* * *$ \\
\hline
\end{tabular}

Note: $*, * *, * * *$ denote $10 \%, 5 \%$, and $1 \%$ levels of significance respectively

Source: 2016 survey results.

In the aspect of income diversification, the SDI varied within the range of 0 (completed dependence on the only income-generating activity) to 1 (the highest level of income diversification). The SDI of the Khmer households in rural areas of the Mekong Delta achieved only 0.132. This number reflected that the Khmer households in rural Mekong Delta highly depended on a limited number of income sources. Strictly speaking, it means that Khmer 
households face a high vulnerability by fluctuations in their income (Adebeyo et al., 2012; Abdulai and CroleRees, 2001). The results of T-test also indicated that there was a statistically significant difference in SDI between poor and non-poor households. Accordingly, poor households had a very low SDI (0.076) compared to non-poor households (0.159). Furthermore, this difference was significantly reflected in all studied provinces.

\subsection{The determinants of poverty and income diversification of the Khmer households}

In this section, this study employed the logit regression model, called Model A, to identify the determinants of poverty (attributed 1 for households with poverty certificates and zero for others). Meanwhile, Model B measures the factors affecting the SDI of the households. To carry out model B, Tobit regression was employed, whereas the dependent variable was SDI (receiving a value from 0 to 1). Both models used the same set of independent variables synthesized from the relevant studies as mentioned above. The final independent variables were categorized into seven variable groups (corresponding to 16 specific independent variables). In contrast, the variables of poverty and SDI were used as the independent variable in the other model. The remaining variables represented by demographic variables $\left(X_{2,3,4,5,6,7}\right)$, property variables $\left(X_{8,9}\right.$, $10,11)$, accessing variables $\left(\mathrm{X}_{12,13}\right)$, religious variables $(\mathrm{X} 14,15)$ while two geographic variables $\left(\mathrm{X}_{16,17}\right)$ were the dummy variables representing Kiengiang province and Soctrang province.

Table 2. Results of regression analysis

\begin{tabular}{|c|c|c|}
\hline Variables & Model A & Model B \\
\hline Dependent variable & Poverty & SDI \\
\hline $\mathrm{X}_{1 \mathrm{~A}} \mathrm{SDI}$ - income diversification index (from 0 to 1 ) & $-1.9981 * *$ & \\
\hline $\mathrm{X}_{1 \mathrm{~B}}$ Poor household ( 1 if poverty certificate holding, 0 if none) & & $-0678 * *$ \\
\hline $\mathrm{X}_{2}$ Gender ( 1 if the head is female, 0 if it is male) & $1.0635 * * *$ & -.0177 \\
\hline $\begin{array}{ll}\mathrm{X}_{3} & \begin{array}{l}\text { Education level of household head ( } 1 \text { if under primary, } 0 \text { if primary or } \\
\text { higher) }\end{array}\end{array}$ & -1521 & 0538 \\
\hline $\mathrm{X}_{4} \quad$ Age of household head (years) & -.0037 & -0008 \\
\hline $\mathrm{X}_{5}$ Household size (number of people) & $.2422 * *$ & .0208 \\
\hline $\mathrm{X}_{6} \quad$ Number of employees (people) & $-2929 *$ & .0019 \\
\hline $\begin{array}{ll}\mathrm{X}_{7} & \text { Number of members going to work far (people) }\end{array}$ & -.1455 & -.0528 \\
\hline $\mathrm{X}_{8} \quad$ Total land area $\left(1000 \mathrm{~m}^{2}\right)$ & $-8800 * * *$ & .0005 \\
\hline $\begin{array}{ll}X_{9} & \text { Household having motorbikes ( } 1 \text { if yes, } 0 \text { if none) }\end{array}$ & $-4477 * *$ & .0248 \\
\hline $\mathrm{X}_{10}$ Household having mobile phones ( 1 if yes, 0 if none) & -.0019 & $.0261 * *$ \\
\hline $\mathrm{X}_{11}$ Household accessing clean water (1 if yes, 0 if none) & $-4800 * *$ & -.0168 \\
\hline $\mathrm{X}_{12}$ Household currently borrowing money from bank (1 if yes, 0 if none) & .0666 & $.1393 * * *$ \\
\hline $\mathrm{X}_{13}$ Household involving in extension activities ( 1 if yes, 0 if none) & -0308 & $.0685 * *$ \\
\hline $\mathrm{X}_{14}$ Any member of household has been the monk ( 1 if yes, 0 if none) & -.1287 & $.0669 * *$ \\
\hline $\mathrm{X}_{15}$ Number of visits to the pagoda during the year (times) & .0092 & $.0024 *$ \\
\hline $\mathrm{X}_{16}$ Kiengiang ( 1 if the household in Kiengiang, 0 if none) & $-1.1592 * * *$ & $-.1254 * * *$ \\
\hline $\mathrm{X}_{17}$ Soctrang (1 if the household in Soctrang, 0 if none) & .0273 & $-.0572 *$ \\
\hline$\alpha \quad$ Constant & -.1472 & -.0919 \\
\hline $\mathrm{N}$ & 390 & 390 \\
\hline Prob> chi 2 & 0.0000 & 0.0000 \\
\hline Pseudo R2 & 0.1854 & 0.2701 \\
\hline
\end{tabular}

Note: *,**,*** denote $10 \%, 5 \%$, and $1 \%$ levels of significance respectively

Source: Survey results, 2016. 
The results of regression analysis in both models reflected that some variables classified into these following groups had significant impacts on Poverty and SDI as follows:

\subsubsection{Effects of poverty and SDI variables}

Both regression models confirmed the findings of some existing studies cited that poverty and income diversification had the significant and positive impact each other. In other words, income diversification could be considered as the most important strategy for raising income and reducing rural poverty of the Khmer community in rural areas. However, the findings mentioned above emphasized that the average income diversification index of Khmer households was very low. The main source of income for the household was heavily dependent on paid employment in the agricultural and non-agricultural sectors, accounting for $68 \%$ of total household income.

\subsubsection{Variable group of demography}

Demographic variables had significant impacts in the model A of poverty instead of the model B of SDI. Specifically, the households with female heads were reflected by their poverty status. The tendency of these households to fall into the category of poor households was higher than that of male-headed households. This finding reflected the higher vulnerability of female heads to male heads in terms of income generating. On the other hand, the size of the household significantly increased the probability of poverty. However, the increase in the number of laborers of the household should be associated with the higher opportunities of incomegenerating members. Thus, there were more opportunities to reduce the probability of falling into the poor household. However, among 390 households interviewed, only 166 adults (accounting $12.31 \%$ of adults in the sample) were not able to read and write in Vietnamese while $19.05 \%$ of adults were able to read or write only. This was a significant barrier to improve the effectiveness of training for Khmer people in order to increase and diversify their income sources.

\subsubsection{Variable group of assets}

Asset variables include the total land areas that households own, the land use right, the probability of households to own motorcycles, mobile phones and use clean water. They determined different impacts on either the probability of poverty or income diversification. Using mobile phones is the only variable in this group that had a significant impact and a positive contribution to the diversification of household's income. Better access to information, including production information, gives the households more opportunities to gain benefits from higher income diversification. Regarding the determinants of poverty of the household, the significant variables such as total land area, motorcycle ownership, and clean water access, were absolutely making difference for the non-poor households. In particular, it is important to emphasize that access to agricultural land is closely related to the probability of poor households. In terms of income sources, the income of Khmer households is heavily dependent on land use. As the above analysis, the main difference in income between poor and non-poor households is mainly due to differences in income sources based on cultivation, livestock, and aquaculture. This source of income is completely linked to household access and land use. 


\subsubsection{Variable group of access}

This group of variables includes access to credit and access to agricultural extension programs. Both of these variables do not have a significant impact on the probability of poverty in the household, but significant impact on income diversification of the household. Among the households borrowing from banks, $65.69 \%$ of households are borrowed for agricultural production. Therefore, enhancing the access of households to credit and improve the efficiency and accessibility of the extension program will enhance its ability to diversify household income through agricultural production diversification.

\subsubsection{Variable group of religion}

Religious variables include specific variables to represent the religious characteristics of the Khmer people in the Mekong Delta. Nowadays, many Khmer households still maintain a distinctive cultural structure, including systems of values, religious beliefs and a strong spiritual linkage to the pagodas (Theravada Buddhism). As a traditional custom, sons aged 12 and older will enter the pagodas and serve as the monks (possibly for months, years or a lifetime). Becoming a monk is a respectful way to express his deep gratitude to parents. Furthermore, the pagodas are also the place where the young monks are able to study, participate in vocational education and training guided by experienced monks (Tran Minh Thuong, 2013). The findings of this study indicate that adherence of the Khmer people to religion and pagodas had positive impacts to diversify the income sources of households, particularly through vocational training activities at the pagodas.

\subsubsection{Variable group of geography}

Many poverty reduction policies are geographically targeted in Vietnam. It may result in different impacts by locations. There are two geographical variables represents for the three provinces of Vietnam with the highest density of the Khmer people. There were dummy variables to show if households were surveyed in Kiengiang province, Soctrang province or rest (Travinh province). Accordingly, the appearance of the surveyed households in Kiengiang province increased the poverty probability of total households. Meanwhile, households in Kiengiang and Soctrang provinces were less diversified in their income than the SDI of households in Travinh province. This result indicated that differences in geographical areas affect the probability of poverty and a household's ability to diversify their income sources. This feature should be emphasized in the policy development on the relationship of equality between ethnic minorities and majorities in the regions.

\section{Conclusion}

According to the objectives of the Vietnam government until 2020, Vietnam will be expected to reduce the poverty rate of ethnic minorities in the country an average of $3 \%-4 \%$ annually (The Prime Minister, 2015a). The main concern of this study was to examine the sustainable economic development of the Khmer - an ethnic minority with more than 1 million people in Vietnam.

A study of ADB (2002) indicated that more than 90 relevant decrees and other official documents focused on the socioeconomic development of ethnic minorities have imposed in Vietnam since Doi Moi (Renovation in 1986). Despite these efforts of the government in policy enforcement, the findings of this study have consistently indicated that the poverty reduction 
for the Khmer seems to be lagging behind compared to the Kinh majority. The Khmer households were showing a low level of economic development compared to the average indicators of the Kinh majority and of the region. The main income of the households depends largely on the source of paid employment earned from jobs with low demand for skills and with low wages.

The most remarkable findings imply that the poverty of Khmer households is very closely associated with the small agricultural areas where they work and the low ability to diversify their income sources, which results in a high vulnerability. The government's policies for economic development in the Khmer community should aim to enhance their opportunities to access to land, credit, and extension to diversify the income and reduce poverty. In addition, participation in religious activities had positive impacts on the diversification of household income - although all these effects might differ between the three provinces selected in this study.

Last but not least, the concept of poverty in this study is understood as a single indicator in order to be compared to the existing secondary data. The multidimensional poverty should be embedded in future studies to ensure that five dimensions, including health, education, house, clean water and sanitation, and information are considered. Since November 2015, the Vietnamese government promulgated the multidimensional approach to poverty for 2016-2020 (The Prime Minister, 2015b). One of the earliest studies on multidimensional poverty in Vietnam of Ha Le et al. (2014) indicated that the Mekong Delta was the poorest region of the country in terms of multidimensional poverty. One of limitations of this study is that the significances of the models are quite low. They might need to incorporate more explainable variables to determine the changes in poverty and SDI. In general, the poverty of the Khmer minority; therefore, should continue to be illuminated to contribute to sustainable poverty reduction policies.

\section{References}

ADB, Asian Development Bank (2002). Indigenous peoples/ethnic minorities and poverty reduction Vietnam.

Adebeyo, C. O., Akogwu, G. O., \& Yisa, E. S. (2012). Determinants of income diversification among farm households in Kaduna state: Application of Tobit regression model. PAT, $8(2), 1-10$.

Alobo, S. (2012). Determinants of Rural Household Income Diversification in Senegal and Kenya. Paper presented at the 6èmes Journées de recherches en sciences sociales SFERINRA-CIRAD. SFER, INRA, CIRAD, Toulouse School of Economics, Paris.

Abdulai, A. \& CroleRees, A. (2001). Determinants of income diversification amongst rural households in southern Mali. Food Policy, 26, 437-452. doi: https://doi.org/10.1016/S0306-9192(01)00013-6

Barrett, Ch. B., Bezuneh, M. \& Aboud, A. (2001). Income diversification, poverty traps and policy shocks in Côte d'Ivoire and Kenya. Food Policy, 26(4), 367-384. doi: http://dx.doi.org/10.1016/S0306-9192(01)00017-3

Bernard, A. S. A., Samuael, A., \& Edward, E. O. (2014). Determinants of income diversification of farm households in the western region of Ghana. Quarterly Journal of International Agriculture, 53(1), 55-72.

Christiaensen, L., Pan, L., \& Wang, S. (2013). Pathways out of poverty in lagging regions: evidence from rural western China. Agricultural Economics, 44(1), 25-44. doi: https://doi.org/10.1111/j.1574-0862.2012.00630.x 
Committee for Ethnic Minority Affairs (2015). Tờ trình về việc phê duyệt một số chỉ tiêu thưc hiện các Mục tiêu Phát triển thiên niên kỷ đối với đồng bào dân tộc thiểu số gắn với Mục tiêu phát triển bền vũng sau năm 2015 (in Vietnamese). Hanoi.

Ellis, F. (2000). The Determinants of Rural Livelihood Diversification in Developing Countries. Journal of Agricultural Economics, 51(2), 289-302. doi: https://doi.org/10.1111/j.1477-9552.2000.tb01229.x

Demombynes, G. \& Hoang Vu, L. (2015). Demystifying poverty measurement in Vietnam Vietnam Development Economics Discussion Paper. Hanoi: World Bank.

GSO (2010). Vietnam Household Living Standards Survey. Hanoi: Statistical Publishing House.

GSO, General Statistics Office of Vietnam (2010). Tổng điều tra dân số và nhà ở Việt Nam năm 2009: Một số chỉ tiêu chủ yếu (in Vietnamese). Hanoi.

GSO, General Statistics Office of Vietnam (2012). Vietnam Household Living Standards Survey. Hanoi: Statistical Publishing House.

GSO, General Statistics Office of Vietnam (2014). Báo cáo Di cư và nghèo 2012 (in Vietnamese). Hanoi.

Ha Le, Nguyen, C. \& Phung, T. (2014). Multidimensional Poverty: First Evidence from Vietnam MPRA Paper: University Library of Munich, Germany.

Ibrahim, H., Rahman, S. A., Envulus, E. E., \& Oyewole, S. O. (2009). Income and crop diversification among farming households in a rural area of north central Nigeria. Journal of Tropical Agriculture, Food, Environment and Extension, 8(2), 84-89.

Escobal, J. (2001). The determinants of nonfarm income diversification in rural Peru. World Development, 29(3), 497-508. doi: https://doi.org/10.1016/S0305-750X(00)00104-2

Zhao, J. \& Barry, P. J. (2013). Implications of different income diversification indexes: the case of rural China. Economics and Business Letters, 2(1), 13-20. doi: https://doi.org/10.17811/ebl.2.1.2013.13-20

Khai, Luu Duc, Kinghan, Ch., Newman, C., \& Talbot, Th. (2013). Non-farm income, diversification and welfare: Evidence from rural Vietnam.

Kozel, V. (2014). Well Begun But Not Yet Done: Progress and Emerging Challenges for Poverty Reduction in Vietnam. Washington, DC: World Bank Group.

Malek, M. A., \& Usami, K. (2009). Determinants of non-farm income diversification in developed villages of Bangladesh. American Journal of Economics and Business Administration, 1(2), 141-149. doi: https://doi.org/10.3844/ajebasp.2009.141.149

Minot, N., Epprecht, M., Anh, Tran Thi Tram, \& Trung, Le Quang (2006). Income diversification and poverty in the Northern Uplands of Vietnam: International Food Policy Research Institute (IFPRI).

Hamburg, M. \& Lubov, A. (1985). Basic statistics: a modern approach. New York: Harcourt Brace Jovanovich.

MPI, Ministry of Planning and Investment (2015). Báo cáo quốc gia: Kết quả 15 năm thực hiện các Mục tiêu Phát triển thiên niên kỷ của Việt Nam (in Vietnamese). Hà Nội.

Sultana, N., Hossain, M. E. \& Islam, M. K. (2015). Income diversification and household wellbeing: A case study in rural areas of Bangladesh. International Journal of Business and Economics Research, 4(3), 172-179. doi: https://doi.org/10.11648/j.ijber.20150403.20

Anh, N. T. \& Nghia, N. T. (2014). Thực trạng, giải pháp xóa đói giảm nghèo đối với đồng bào dân tộc Khmer ở khu vực Đồng bằng sông Cửu Long (in Vietnamese). Can Tho University Journal of Science, 30, 84-91.

Nguyen Thi Thu Ha, Nguyen Viet Nga, Nguyen Thanh Phuong, \& Nguyen Văn Thuc (2015). Báo cáo tổng quan các nghiên cứu về giảm nghèo ở Việt Nam (in Vietnamese): Vietnam Ministry of Labour - Invalids and Social Affairsi, Irish Aid, UNDP.

Oxfam (2013). Bất bình đẳng gia tăng: Người dân nghĩ gì? (in Vietnamese). Hanoi. 
Duyen, P. M. (2015). Một số giải pháp giảm nghèo vùng Đồng bằng sông Cửu Long (in Vietnamese). Journal of Development and Intergration, 21(31), 69-77.

Dimova, R. \& Sen, K. (2010). Is household income diversification a means of survival or a means of accumulation? Panel data evidence from Tanzania. BWPI Working Paper, 122.

Schwarze, S. \& Zeller, M. (2005). Income diversification of rural households in central sulawesi, Indonesia. Quaterly Journal of International Agriculture, 44(1), 61-73.

The Prime Minister (2015a). Quyết định 1557/QĐ-TTg về việc Phê duyệt một số chỉ tiêu thưc hiện các Mục tiêu Phát triển thiên niên kỷ đối với đồng bào dân tộc thiểu số găn với mục tiêu phát triển bền vũng sau năm 2015 (in Vietnamese).

The Prime Minister (2015b). Quyết định số 59/2015/QĐ-TTg về việc ban hành chuẩn nghèo tiếp cận đa chiều áp dụng cho giai đoạn 2016-2020 (in Vietnamese).

Tran Minh Thuong (2013). Đi tu báo hiếu của người Khmer Sóc Trăng (in Vietnamese). Retrieved 26/10/2016, from https://www.soctrang.gov.vn/wps/wcm/connect/b22b7100405c1bec8ff4ff6a3b7591b5/B ai+11_01-2013.pdf?MOD=AJPERES

Van De Walle, D., \& Cratty, D. (2004). Is the emerging non-farm market economy the route out of poverty in Vietnam? Economics of Transition, 12(2), 237-274. doi: 10.1111/j.09670750.2004.00178.x

Wanyama, M., Mose, L. O., Odendo, M., Okuro, J. O., Owuor, G., \& Mohammed, L. (2010). Determinants of income diversification strategies amongst rural households in maize based farming systems of Kenya. African Journal of Food Science, 4(12), 754-763.

Zhao, J. \& Barry, P. J. (2014). Income Diversification of Rural Households in China. Canadian Journal of Agricultural Economics/Revue canadienne d'agroeconomie, 62(3), 307-324. doi: $10.1111 /$ cjag. 12033 